\title{
MODEL BIMBINGAN PENGEMBANGAN AKTUALISASI DIRI TERHADAP KEGIATAN NON AKADEMIK MAHASISWA PROGRAM STUDI MATEMATIKA UNIVERSITAS PGRI YOGYAKARTA
}

\author{
Iis Lathifah Nuryanto' ${ }^{1)}$ Niken Wahyu Utami ${ }^{2)}$ \\ Program Studi Bimbingan dan Konseling \\ Fakultas Keguruan dan Ilmu Pendidikan \\ Universitas PGRI Yogyakarta \\ E-mail: iis.0608392@gmail.com
}

\begin{abstract}
Abstrak
Tujuan akhir penelitian adalah menghasilkan model pengembang anak aktualisasi diri yang efektif untuk mengembangkan kegiatan non akademik mahasiswa. Metode penelitian ini adalah mix method dengan menggunakan pendekatan Research and development. Desain penelitian adalah one grouppretest-posttest design. Sampel penelitian sebanyak 27 orang mahasiswa. Hasil penelitian diperoleh model pengembangan aktualisasi diri yang efektif untuk mengembangkan kegiatan non akademik mahasiswa dengan nilai sig $=0,0001<0,05$ n 27=0,67 maka Ho ditolak, maka ada perbedaan sebelum dan sesudah perlakuan menggunakan model pengembangan aktualisasi diri. Rekomendasi yaitu bagi dosen konselor, bagi dosen pembimbing akademik dan bagi pihak Unit PelaksanaTeknis (UPT) dapat dijadikan rujukan dalam memperluas lagi kajian bimbingan untuk mahasiswa-mahasiswa khususnya di UPY dan pada umumnya di seluruh universitas di Indonesia. Untuk peneliti selanjutnya agar mempertimbangkan kembali, (1) metode penelitian, (2) populasi dan sampel dan (3) memperluas lagi kajian penelitian yang dibatasi pada aspek pengetahuan dan sikap saja.

Kata kunci :Model Pengembangan Aktualisai Diri, Kegiatan Non Akademik
\end{abstract}

\begin{abstract}
The final goal of research is to produce a model of self-actualization child developers to develop an effective non-academic activities of the students. This research method is a method using a mix Research and development approach. The study design was one grouppretest-posttest design. The research sample as many as 27 students. The results obtained by the development model of effective self-actualization to develop nonacademic activities of students with sig $=0.0001<0.05 n 27=0.67$ then Ho is rejected, then there is no difference before and after treatment using a model of the development of self-actualization. Recommendations are for faculty counselors for academic lecturers and for the PelaksanaTeknis Unit (UPT) can be used as reference in further expanding the study guidance for students especially in UPY and generally at all universities in Indonesia. For the next researcher to reconsider, (1) a method of research, (2) the sample population, and (3) expand more research studies are limited to the aspects of knowledge and attitude alone.
\end{abstract}

Key words: Model Development of Self Actualization, Non-Academic Activity

\section{Info Artikel}

Diterima Desember 2016, disetujui Desember 2016, diterbitkan Desember 2016 


\section{PENDAHULUAN}

Kompetensi yang dimiliki seseorang akan berpengaruh terhadap kemampuan seseorang dalam melaksanakan kewajibannya. Kemendiknas No.045/U/2002 pasal 1 menyatakan bahwa yang dimaksud dengan kompetensi adalah seperangkat tindakan cerdas, penuh tanggungjawab yang dimiliki seseorang sebagai syarat untuk dianggap mampu oleh masyarakat dalam melaksanakan tugas- tugas di bidang pekerjaan tertentu.

Kemampuan seseorang dalam melaksanakan tugas tertentu dalam dunia kerja dibutuhkan sekitar 20\% penguasaan IPTEKS dan $80 \%$ kemampuan interpersonal skill dan intrapersonal skill. Kompetensi tersebut dapat dibentuk atau dihasilkan dari program studi tempat yang bersangkutan belajar. Akan tetapi, kenyataan yang terjadi selama ini kompetensi yang dihasilkan dari perguruan tinggi sekitar $80 \%$ penguasaan IPTEKS dan baru 20\% kemampuan interpersonal skill dan intrapersonal skill.

Kekurangan-kekurangan yang ada dalam perguruan tinggi untuk meningkakan kemampuan interpersonal skill dan intrapersonal skill sebenarnya dapat dilengkapi dengan kegiatan non akademik mahasiswa. Kegiatan non akademik yang ada di Universitas PGRI Yogyakarta (UPY) diantaranya : Unit Kgiatan Mahasiswa (UKM) tari, UKM taekwondo, UKM silat, UKM paduan suara, UKM MENWA, UKM MAPALA, UKM Olahraga Bulutangkis, UKM PRAMUKA dan UKM Musik.

Prestasi yang diraih oleh mahasiswa dalam kegiaan akademik maupun non akademik adalah wujud potensi mahasiswa yang telah dikembangkan secara optimal dalam rangka memenuhi kebutuhan aktualisasi dirinya sebagai manusia yang utuh. Utuh berarti mencakup dimensi-dimensi aktualisasi diri menurut Rogers yaitu (1) kecakapan intrapersonal, (2) kecakapan interpersonal dan (3) kecakapan interaktif dengan sesama. Berbagai kegiatan mahasiswa yang meliputi kegiatan akademik maupun non akademik merupakan salah satu bentuk aplikasi dalam mengembangkan aktualisasi diri mahasiswa.

Fenomena yang terjadi saat ini terdapat beberapa kegiatan non akadmik mahasiswa yang menjadi salah satu sarana mahasiswa dalam mengembangkan potensinya. Penelitian oleh Lina Fitri Kumalasari (2010) dengan judul penelitian PERBEDAAN PRESTASI BELAJAR BERDASAR TINGKAT AKTIVITAS DALAM ORGANISASI EKSTRAKURIKULER PADA MAHASISWA D IV KEBIDANAN UNS (Universitas Sebelas Maret) Surakarta, mengungkapkan bahwa Aktivitas dalam organisasi non akademik merupakan salah satu faktor yang mempengaruhi prestasi belajar. 
Dengan mengikuti kegiatan dalam organisasi non akademik, mahasiswa dapat mengembangkan bakat dan minta serta dapat mengembangkan kemampuan kognitif, afektif dan psikomotorik mereka. Dengan Hasil penelitian dari 53 responden menunjukkan bahwa terdapat perbedaan prestasi belajar antara mahasiswa yang aktif organisasi non akademik dengan yang tidak aktif organisasi non akademik. Mahasiswa yang aktif dalam organisasi non akademik mempunyai prestasi yang lebih baik dari pada mahasiswa yang tidak aktif dalam organisasi non akademik. Berdasarkan hasil uji statistik diperoleh $\mu 1=3,105$ dan $\mu 2=2,7940(\mu 1>\mu 2)$ dengan signifikansi $0,003(\mathrm{P}<0,05)$.

Berdasarkan uraian tersebut, pengembangan aktualisasi diri mahasiswa terhadap kegiatan non akademik sangat penting, dengan berkembangnya aktualisasi diri maka meningkat pula prestasi mahasiswa dalam kegiatan akademik maupun non akademik

\section{METODE PELAKSANAAN}

Rancangan tahapan-tahapan kegiatan dalam penelitian ini digambarkan dalam gambar 1 berikut.
Gambar 1.

\section{Tahapan Penelitian}

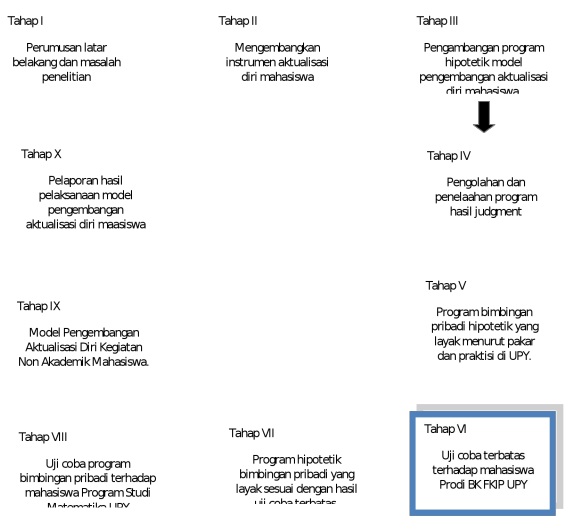

HASIL

DAN

\section{PEMBAHASAN}

Prosedur penelitian yang dilakukan dalam penelitian ini meliputi tiga tahap, yaitu tahapan persiapan, pelaksanaan, analisis data, dan pelaporan. Kegiatan yang dilakukan dalam penelitian ini adalah sebagai berikut.

\section{Hasil Penelitian}

Prosedur penelitian yang dilakukan dalam penelitian ini meliputi tiga tahap, yaitu tahapan persiapan, pelaksanaan, analisis data, dan pelaporan.

1) Tahapan Persiapan

Tujuan tahap ini adalah untuk mempersiapkan perangkat penelitian setelah menganalisis permasalahan pembelajaran. Kegiatan pada tahap ini meliputi analisis permasalahan pembelajaran, analisis konsep, penyusunan instrumen, dan penyusunan perangkat. Uraiannya adalah sebagai berikut.

a. Analisis permasalahan 
Permasalahan yang seringkali ditemui mahasiswa dalam mengembangkan aktualisasi diri terhadap kegiatan nonakadmik adalah pemahaman mahasiswa tentang potensi diri belum optimal.

b. Analisis konsep materi

Pengembangan aktualisasi diri mahasiswa yaitu mencakup kecakapan intrapersonal (kesadaran diri, peninjauan diri, penghargaan diri dan adaptasi diri), kecakapan interpersonal (empati, hormat, ramah dan membimbing), kecakapan interaktif (humor, toleransi, berperan layak dan mengatasi konflik). Layanan bimbingan dibagi dalam beberapa materi, yaitu :

1) Mengetahui kelebihan dan kelemahan diri

2) Mengetahui nilai-nilai dalam diri

3) Dimana tempat ternyamanku

4) Doa terbaik untukmu

5) Sosiodrama

c. Penyusunan instrumen

Instrumen penelitian yang disusun dalam penelitian ini adalah instrumen angket aktualisasi diri mahasiswa.

d. Penyusunan model bimbingan aktualisasi diri

Perangkat model bimbingan aktualisasi diri yang disusun dalam kegiatan penelitian meliputi Rancangan
Pelaksanaan Layanan (RPL)

Bimbingan dan Konseling.

2) Tahapan Pelaksanaan

Tahap pelaksanaan penelitian ini adalah uji coba instrumen dan pelaksanaan penelitian kuasi eksperimen. Pelaksanaan yang dimaksud meliputi:

a. Uji coba Instrumen Angket Aktualisasi Diri Mahasiswa, Instrumen yang digunakan dalam kegiatan penelitian terlebih dahulu diujicoba di kelas lain, dalam hal ini di kelas 5A2.

b. Penerapan Layanan Bimbingan Penerapan layanan bimbingan di kelas 5A3.

c. Pemberian Angket Aktualisasi Diri Mahasiswa

Langkah pemberian angket dilakuikan sebelum dan setelahlayanan bimbingan dilaksanakan sebagai pembanding hasil pre-test dan post-test.

3) Tahapan Analisis Data

1. Uji Coba Instrumen

Angket sebagai alat pengumpul data yang dipergunakan telah melalui beberapa tahap pengujian, sebagai berikut.

a. Uji Kelayakan Instrumen

Uji kelayakan instrumen ini bertujuan untuk mengetahui tingkat kelayakan instrumen dari segi bahasa, isi dan konstruk (segi materi dan redaksional). 


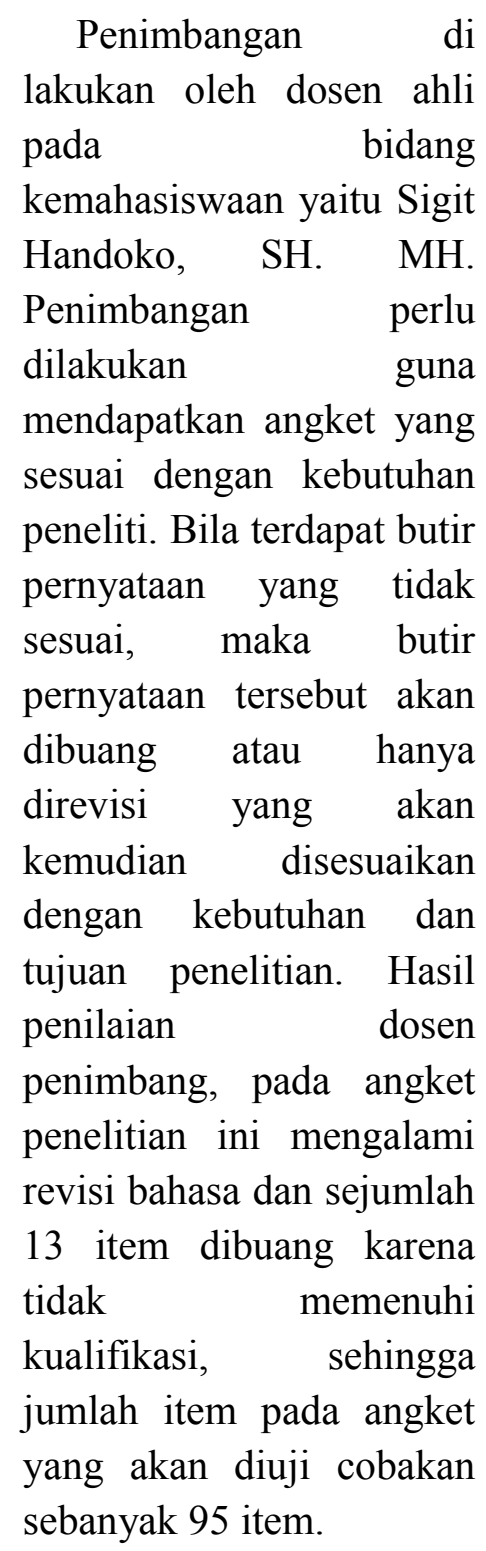

b. Uji Keterbacaan

$\begin{array}{lr}\text { Uji } & \begin{array}{r}\text { keterbacaan } \\ \text { kepada }\end{array} \\ \text { dilakukan } & \text { tidak } \\ \text { mahasiswa yang } & \text { anggota sampel } \\ \text { dijadikan an } 5 \\ \text { penelitian sebanyak } 5 \\ \text { orang untuk mengukur } \\ \text { sejauh mana keterbacaan } \\ \text { instrumen dengan tujuan } \\ \text { untuk mengetahui kata- } \\ \text { kata yang kurang } \\ \text { dipahami, sehingga }\end{array}$

kalimat dalam pernyataan dapat disederhanakan tanpa mengubah maksud dari pernyataan tersebut.

Setelah uji keterbacaan, maka untuk pernyataanpernyataan yang tidak dipahami kemudian direvisi sesuai dengan kebutuhan sehingga dapat dimengerti oleh usia remaja dan kemudian dilakukan uji validitas dan reliabilitasnya.

c. Uji Coba (try out) Instrumen

Instrumen ini diujicobakan pada 30 orang mahasiswa Program Studi Pendidikan Matematika Universitas PGRI Yogyakarta. Uji coba ini dilakukan sekaligus dengan pengumpulan data penelitian. Uji coba ini dimaksudkan untuk mengetahui ketepatan / kesahihan (validity) dan keterandalan (reliability) alat ukur yang telah disusun dan akan digunakan penelitian.

d. Uji Validitas

Kriteria
digunakan adalah item
yang memiliki $t_{\text {hitung }}>t_{\text {tabel }}$
dinyatakan sebagai item
yang valid dan apabila
$t_{\text {hitung }}<t_{\text {tabel }}$ dikatakan invalid.

Dipublikasikan Oleh: Program Studi Bimbingan dan 
Pada tarap kepercayaan 95

$\%$ diperoleh harga $t_{\text {tabel }}$ sebesar 0, 312. Diantara sejumlah 32item yang diujicobakan, hanya diperoleh 31 item yang memenuhi kriteria penerimaan $r$ tersebut.

Tabel 1

Hasil Uji Validitas Instrumen

\begin{tabular}{|c|l|l}
\hline KESIMPULAN & ITEM & JUMI \\
\hline Memadai & $2,4,7,14,15,17,18,20,21,22,23,30,31,32,33,34$, & 31 \\
& $35,36,37,38,39,40,41,43,44,45,46,47,48,50,51$ & \\
\hline Buang & $\begin{array}{l}1,3,5,6,8,9,10,11,12,13,16,19,24,25,26,27,28, \\
29,42,49,52\end{array}$ & 21 \\
\hline
\end{tabular}

e. Uji Reliabilitas

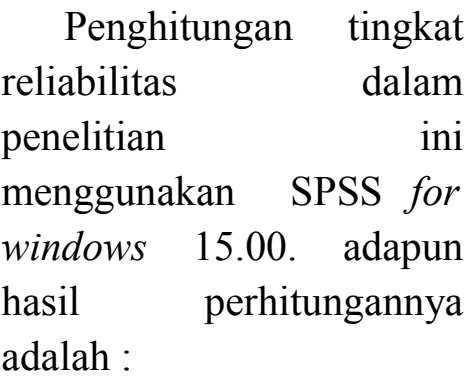

Tabel 2

Hasil Uji Reliabilitas Instrumen

Reliability Statistics

\begin{tabular}{|l|l|}
\hline $\begin{array}{l}\text { Cronbach's } \\
\text { Alpha }\end{array}$ & N of Items \\
\hline .887 & 31 \\
\hline
\end{tabular}

Berdasarkan hasil perhitungan dengan SPSS, nilai alpha $=0,887$. $\mathrm{R}$ tabel untuk $\mathrm{n}=32$ dan alpha 5\% adalah 0,349 . Oleh karena alpha $=0,887>\mathrm{r}$ tabel $=$ 0,349, dapat disimpulkan bahwa item-item daliPaired Samples Statistics

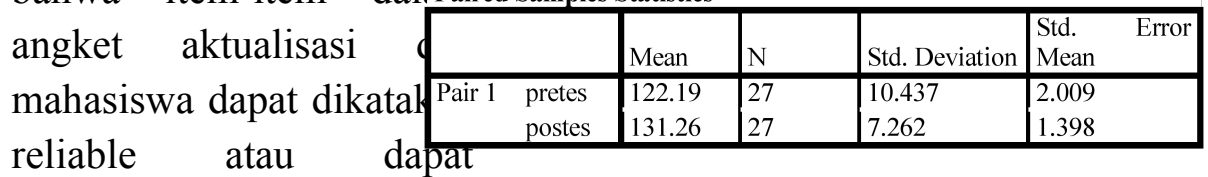
Dipublikasikan Oleh: Program Studi Bimbingan dan dipercaya sebagai alat pengumpul data dalam penelitian.

2. Uji Prasyarat

Sebelum dilakukan uji t, terlebih dahulu dilakukan uji prasyarat yang dilakukan dalam penelitian ini meliputi uji normalitas sebaran data dan uji homognitas varians.

Tabel 3

Uji Normalitas Data

\begin{tabular}{|c|c|c|}
\hline & & $\begin{array}{l}\text { VAR0000 } \\
1\end{array}$ \\
\hline $\begin{array}{l}\text { N } \\
\text { Normal Parameters }{ }^{\mathrm{a}, \mathrm{b}} \\
\text { Most Extreme } \\
\text { Differences } \\
\text { Kolmogorov-Smirnov Z } \\
\text { Asymp. Sig. (2-tailed) }\end{array}$ & $\begin{array}{l}\text { Mean } \\
\text { Std. Deviation } \\
\text { Absolute } \\
\text { Positive } \\
\text { Negative }\end{array}$ & $\begin{array}{l}27 \\
122.19 \\
10.437 \\
.080 \\
.080 \\
-.076 \\
.415 \\
.995\end{array}$ \\
\hline
\end{tabular}

Berdasarkan hasil SPSS tersebut, diperoleh nilai sig $=0,995>0,05$, artinya data yang kita uji berdistribusi normal.

3. Uji Hipotesis

Setelah dilakukan uji prasyarat terhadap data tentang aktualisasi diri mahasiswa Program studi Pendidikan Matematika, maka dapat dilakukan uji t terhadap hasil pretest dan posttest dengan hasil sebagai berikut. 


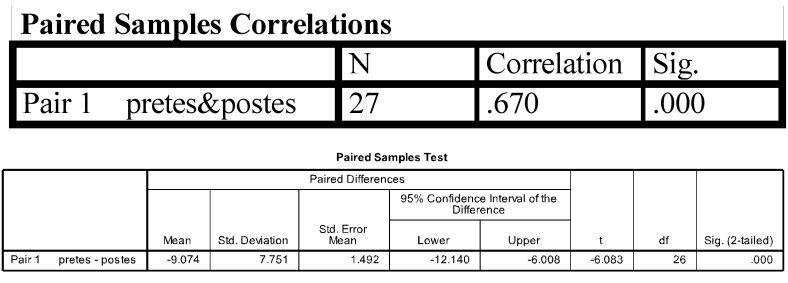

Berdasarkan hasil $t$ test menggunakan SPSS di atas, dapat disimpulkan bahwa Ho tidak ada perbedaan sebelum dan sesudah pembimbingan menggunakan model aktualisasi diri yang dikembangkan, sedangkan $\mathrm{Ha}$ ada perbedaan sebelum dan sesudah pembimbingan menggunakan model aktualisasi diri yang dikembangkan

Dapat diambil keputusan bahwa nilai yang diperoleh sig $=0,0001<0,05$ maka Ho ditolak, dengan kata lain: Ada perbedaan sebelum dan sesudah pembimbingan menggunakan model aktualisasi diri yang dikembangkan.

Adapun hasil uji $t$ dapat dilihat lebih jelas pada Grafik berikut.

\section{Grafik 1}

\section{Hasil Ketercapaian Pretest-Posttest}

Persentase Ketercapaian Pretes-Postes

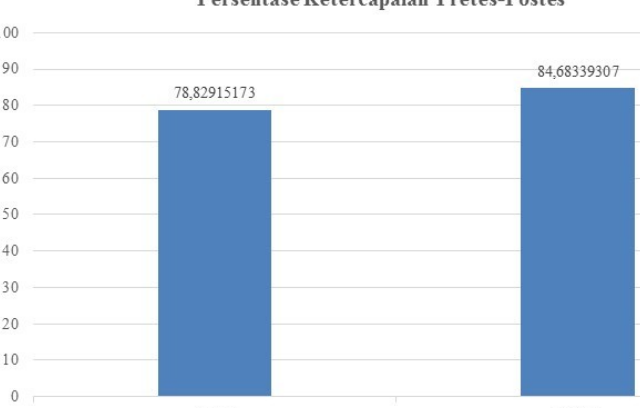

\section{Pembahasan}

Model pengembangan layanan bimbingan aktualisasi diri mahasiswa yang dilaksanakan memiliki beberapa aspek yaitu aspek intrapersonal, interpersonal dan interaksi. Sebagai tujuan utama keberhasilan model pengembangan layanan bimbingan sejatinya memperhatikan ketiga aspek tersebut. Pada saat diperoleh data awal, mahasiswa Program Studi Pendidikan Matematika FKIP Universitas PGRI Yogyakarta berada pada kategori cukup, hal ini serupa dengan hasil studi pendahuluan saat dilakukan observasi.

Setelah diperoleh hasil pretest pada mahasiswa Pendidikan Matematika, maka peneliti merumuskan model pengembangan dengan fokus pada struktur dan tahapan model yang akan diberikan. Peneliti memberi perlakuan pada tangal 1-10 September 2016 terhadap 27 mahasiswa, dengan menggunakan RPL yang telah dibuat sebelumnya. RPL yang telah dirumuskan berjudul :

1) Mengetahui kelebihan dan kelemahan diri

Dalam kegiatan ini, mahasiswa dikodisikan untuk mengubah posisi duduknya menjadi melingkar membuat lingkaran

Studi Bimbingan dan Konseling itas PGRI Yogyakarta 


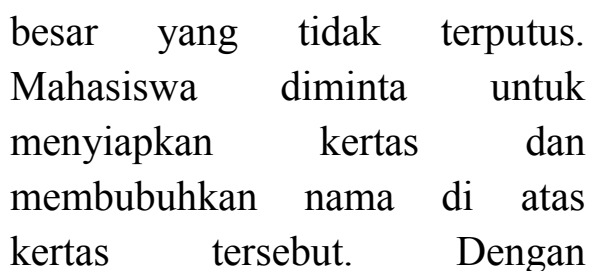
mendengar aba-aba dari peneliti, maka mahasiswa memindahkan kertas tersebut kearah jarum jam. Tugas mahasiswa adalah menilai teman yang namanya tersedia di kertas tersebut.

2) Mengenali nilai-nilai dalam diri

Mahasiswa diberikan beberapa pilihan profesi yang sering ditemui sehari-hari. Kemudian mahasiswa diberikan arahan untuk mempromosikan profesi tersebut sesuai dengan bakat dan minatnya masing-masing, seakan ingin memberikan informasi pada khalayak umum bahwa profesi yang mereka pilih adalah profesi terbaik.

3) Dimana tempat ternyamanku

Mahasiswa diarahkan untuk keluar dari kelas, dan diberi petunjuk untuk masuk ke kelas satu persatu. Saat mereka sudah memiliih tempat yang paling nyaman, maka peneliti menjelaskan bahwa tempat yang dipilihnya mencerminkan kondisi dan suasana hatinya.

4) Doa terbaik untukmu

Mahasiswa dibentuk kelompok kecil sejumlah 5-6 orang mahasiswa. Peneliti memberikan arahan untuk mahasiswa bergantian memberikan doa terbaik bagi teman sekelompoknya.

5) Sosiodrama

Berdasarkan kegiatan kedua, yaitu mengetahui nilai-nilai dalam diri, maka peneliti menunjuk beberapa perwakilan mahasiswa untuk maju ke depan, memerankan peran yang sudah ditetapkan oleh peneliti beserta alur ceritanya. Teman yang lain menyimak dan memberikan masukan dan evaluasi terhadap sosiodrama yang telah dilaksanakan.

Kegiatan mengetahui kelebihan dan kelemahan diri, mengetahui nilainilai dalam diri, menunjang beberapa indikator aktualisasi diri yaitu kesadaran diri, peninjauan diri, penghargaan diri. Mahasiswa semester 3 termasuk pada fase perkembangan dewasa awal. Maka, tugas perkembangan yang seharusnya dilalui adalah mampu menyadari diri akan kelebihan dan kelemahannya, dan mampu menghargai dri serta orang lain di lingkungan sekitarnya.

Kegiatan dimana tempat ternyamanku dapat memberikan perubahan dalam adaptasi diri mahasiswa. Mahasiswa yang terkadang kurang mampu beradaptasi dengan lingkungan, mengingat mahasiswa masih semester 3 . Kegiatan layanan ini memberikan kontribusi, karena dinilai mahasiswa dapat memilih tempat yang dinilainya sangat nyaman ketika hendak belajar di kelas. 
Kegiatan layanan ke empat yaitu Doa terbaik untukmu dapat memberikan kontribusi pada indicator aktualisasi diri yaitu empati, hormat, ramah, mebimbing. Melalui kata-kata yang diberikan kepada temannya memperlihatkan bahwa mahasiswa tersebut dapat memberikan hal positif pada orang lain dan dirinya sendiri.

Sedangkan kegiatan terakhir yaitu sosiodrama, dapat mengungkap beberapa indicator yaitu humor, toleransi, berperan layak dan mengatasi konflik. Mahasiswa yang memerankan dalam alur cerita sosiodrama dapat memberikan nyawa tersendiri pada perannya masingmasing, teman lainnya memberikan masukan pada pemeran.

Setelah diberikan perlakuan tersebut, dilakukan posttest kepada mahasiswa dan diperoleh hasil pretest sebesar 78,87 kemudia hasil posttest 84,68 bahwa mahasiswa Pendidikan Matematika berada pada kategori Sangat Tinggi. Hal ini menunjukkan bahwa pelaksanaan Model Pengembangan Aktualisasi Diri terhadap kegiatan non akademik mahasiswa efektif.

\section{SIMPULAN DAN SARAN}

\section{Simpulan}

Berdasarkan hasil analisis terhadap hasil penelitian yang dilakukan, dapat disimpulkan hasil penelitian sebagai berikut. a. Struktur dan tahapan model layanan bimbingan pribadi sosial dapat digunakan menurut Pakar/ahli, dalam melaksanakan kegiatan layanan bimbingan kepada mahasiswa Pendidikan Matematika FKIP UPY.

b. Hasil ujicoba model, dan uji keefektifan model dapat diuji sehingga diperoleh kesimpulan bahwa model layanan bimbingan dapat mengembangkan aktualisasi diri mahasiswa.

\section{Saran}

Berdasarkan kesimpulan penelitian tersebut, dapat diberikan saran yaitu :

a. Bagi dosen pembimbing akademik Model pengembangan aktalisasi diri terhadap kegiatan non akademik mahasiswa dapat digunakan dalam memfasilitasi pengembangan aktualisasi diri pada mahasiswa Program Studi Matematika FKIP Universitas PGRI Yogyakarta

b. Bagi peneliti selanjutnya

Model pengembangan aktalisasi diri terhadap kegiatan non akademik mahasiswa dapat digunakan sebagai referensi dalam menulis peelitian yang bertema aktualisasi diri.

\section{DAFTAR PUSTAKA}

Arikunto, Suharsimi. (2006). Prosedur Penelitian: Suatu Pendekatan Praktik. Jakarta: PT. Rineka Cipta. 
Archer. (1994). Interventions For Adolescent Identity Development. USA. Sage Publications.

Borg. W.R.\&Gall. M.D. (1989).Educational research an Introduction fifth Edition. Newyork. Logman.

Cavanagh, Michael \& Levitov. Justin E.(2002). The Counseling Experience $A$ Theoriticaland Practical Approach. USA: Wafeland Press, Inc.

Chaplin, J.P. (2002). Kamus Lengkap Psikologi. Jakarta: Raja Grafindo Persada.

Choesin, Ezra M., Suhardiyanto, Totok, Winarto, Yunita T., (2007). Karya Tulis Ilmiah Sosial-Menyiapkan, Menulis dan Mencermatinya. Jakarta. Yayasan Obor Indonesia.

Covey, Sean (2001) 7 Kebiasaan Remaja yang Sangat Efektif, alih bahasa : Arvin Saputra. Jakarta : Binarupa Aksara

Furqon.(2004). Statistika Terapan Untuk Penelitian. Bandung. ALFABETA.

Hill, John P. (1993). Adolescence. United State of America.

Hurlock, E. (1980). Psikologi Perkembangan: Suatu Pendekatan Sepanjang Rentang Kehidupan.Jakarta: Erlangga

Ibrahim, Muhammad. (2000). Hubungan Antara Sikap
Terhadap Nilai-nilai Budaya dan Eksplorasi dan Komitmen dalam Pencapaian Status Identitas Remaja Akhir Bidang Perkawinan (Studi pada Mahasiswa).Tesis. Program Pascasarjana UNPAD Bandung

Luyckx, Koen., Schwartz, Seth J., Vignoles, Vivian L., (2010). Handbook of Identity Theory an Research. USA. Springer.

Mappiare, Andi. (2006). Kamus Istilah Konseling dan Terapi. Jakarta. rajaGrafindo Persada.

Mar'at, Samsunumyati. (2006). Desmita Psikologi Perkembangan. Bandung. Rosda.

Marcia, J.E. (1993) Ego Identity. New York. Springer-Verlag.

McInerney, Dennis M., (2006). Developmental Psychology For Teachers. - an Aplied Approach. Australia. Unwin.

Nasution, S. (2007).Metode ResearchPenelitian Ilmiah. Jakarta. Bumi Aksara.

Nurihsan, Juntika. (2003). DasarDasar Bimbingan dan Konseling.Bandung: Mutiara.

Nurihsan, Juntika dan Sudianto. (2004). Strategi Layanan Bimbingan dan Konseling. Bandung: Rosdakarya.

Nurihsan, Juntika dan Sudianto. (2006). Bimbingan dan Konseling dalam Berbagai 
Latar Kehidupan. Bandung: RefikaAditama.

Nurihsan, Juntika. (2012). Program Unit Pelaksana Teknis Layanan Bimbingan dan Konseling. Bandung. UPI.

Purwanto, Ngalim. (1990). Psikolgi Pendidikan. Bandung. PT. Remaja Rosdakarya.

Riduwan. (2006). Belajar Mudah Penelitian Untuk Guru, Karyawan dan Peneliti Pemula. Bandung: Alfabeta.

Riduwan.(2010) Metode dan Teknik Menyusun Tesis. Bandung. Alfabeta.

Rusmana, nandang.(2009). Bimbingan dan Konseling Kelompok di Sekolah (Metode, Teknik dan Aplikasi). Bandung. Rizai.

Rusmana, Nandang. (2009). Konseling Kelompok Bagi Anak Berpengalaman Traumatis. Bandung. Rizqi.

Saliyanto.(2012). Analisis Statistik Pendekatan Praktir Microsoft Office Excel.Yogyakarta.ANDI.

Santrock, John W., (2002). Life-Span Development-Perkembangan Masa Hidup. Jakarta. Erlangga. Sudjana.(1996). Metoda Statistika Edisi ke-6. Bandung. TARSITO.

Sugiyono.(2005). Statistika untuk Penelitian. Bandung. ALFABETA.
Suherman, Uman. (2007). Manajemen Bimbingan dan Konseling.Bekasi. Madani Productin.

Sukardi.(2003). Metodologi Penelitian PendidikanKompetensi dan Praktiknya. Jakarta. Bumi Aksara.

Sukardi.(2008). Meodologi Penelitian Pendidikan Kompetensi dan Praktiknya.Jakarta. Bumi Aksara.

Sukmadinata.(2003). Landasan Psikologi Proses Pendidikan. Bandung. PT Remaja Rosdakarya.

Supranto.(1992) Teknik Sampling. Jakarta. Rineka Cipta.

Sobur, Alex. (2003). Psikologi Umum. Bandung. CV Pustaka Setia.

Surya, Mohamad. (2009). Psikologi Konseling. Bandung: Maestro.

Suryabrata, Sumardi. (2004). Psikologi Pendidikan. Jakarta. Rajagrafindo Persada.

Syamsudin, Abin.(1999). Psikologi Kependidikan. Bandung: Rosda Karya.

Widyatama, Rendra. (2006). Bias Gender.Yogyakarta. Media Pressindo.

Winkel, W.S. (1997). Bimbingan dan Konseling di Institusi Pendidikan. Jakarta: Grasindo. 
Yusuf, LN, Syamsu. (2005). Psikologi

Perkembangan Anak dan Yusuf, LN, Syamsu.\&Nurihsan, Remaja. Bandung. Rosda. Juntika. (2007). Teori

Yusuf, LN, Syamsu.\&Nurihsan, Kepribadian.Bandung. Rosda. Juntika. (2005). Landasan Bimbingan dan Konseling. Bandung. Rosda. 